\title{
Consumption metrics of chardonnay wine consumers in Australia
}

\author{
This article was published in the following Dove Press journal: \\ International Journal of Wine Research \\ 25 February 2015 \\ Number of times this article has been viewed
}

\author{
Anthony J Saliba' \\ Johan Bruwer ${ }^{2}$ \\ Jasmine B MacDonald' \\ 'School of Psychology, Charles Sturt \\ University, Bathurst, NSW, ${ }^{2}$ School \\ of Marketing, University of South \\ Australia, Adelaide, SA, Australia
}

\begin{abstract}
There is a dearth of information in the knowledge base about who the chardonnay consumer is, what their wine-consumption metrics are, what sensory characteristics they associate chardonnay with, and who influenced their perceptions. This study examines the consumer engagement with chardonnay, and contributes evidence-based research to inform future wine-business strategy. A population sample was recruited to be representative of Australian consumers. An online survey of 2,024 Australian wine consumers was conducted, 1,533 (76\%) of whom actually consumed chardonnay. This paper focuses only on those who consumed chardonnay. Males purchased and consumed larger quantities of chardonnay, although marginally more females consumed it. Chardonnay is considered to be characterized by full, lingering, and fruity flavors, as well as yellow color. Chardonnay is associated with dinner parties and at-home consumption. The vast majority of participants liked and had a positive perception of chardonnay. The target market for chardonnay is not only females; in fact, males appear to be the main consumers of this varietal by volume. Marketing and promotion campaigns should leverage the findings to retain current and win back other consumers. This is the first research to provide empirical explanations of consumer engagement with chardonnay, and to contribute evidence-based research in this regard.
\end{abstract}

Keywords: chardonnay, consumer behavior, wine style, wine consumption, Australia

\section{Introduction}

The Australian grape and wine industry has expanded steadily for the past two decades to become the seventh-largest producer and the fourth-largest exporter in the world, ${ }^{1}$ with chardonnay being one of the most prominent varieties. ${ }^{2}$ Although introduced into Australia in 1832 by James Busby, ${ }^{3}$ commercial chardonnay production did not begin until the early 1970s. Since then, production has increased substantially, and the Australian wine industry owes a large portion of its modern-day success to chardonnay, which has arguably been its backbone for more than two decades. It is the most planted white variety, because of its solid viticultural properties and ability to provide flexible wine styles. Chardonnay contributed 397,239 tons or $22 \%$ of the 2013 grape-tonnage crush, ${ }^{4}$ from 25,359 hectares of chardonnay-bearing vineyards. ${ }^{5}$ For the year 2013/2014, white wine accounted for $56 \%$ of Australian domestic volume sales of wine. ${ }^{6}$ Nearly $45 \%$ of the 2013 white grape-variety tonnage crush came from chardonnay, ${ }^{4}$ further underlining the significance of chardonnay.

However, in recent years, there have been indications that chardonnay has become relatively unpopular. One explanation is that general opinion has shifted toward fresher, lighter-bodied, more predictable wine styles, such as sauvignon blanc. ${ }^{7}$ Given that 
little consumer sensory research has focused on chardonnay, consumer sensory-preference mapping is needed in order to understand how the effect of taste and perception interact and how sales are affected. ${ }^{8}$

In the absence of this research, there has been a tendency to rely on individuals" "expert" opinions, as well as considered analyses that have not always been based on reliable data. This may have led the industry to conclude, incorrectly, that consumer attitude toward chardonnay has recoiled. Many different theories have been advanced by publicists, key wine-industry personnel, sales representatives, managers, and others to explain chardonnay's declining popularity, but to date an empirical explanation is still lacking. Our study examines consumer engagement with chardonnay and contributes evidence-based research to inform future wine business strategy.

\section{Literature framework}

\section{Recent decline in chardonnay's popularity}

Historically, chardonnay production has concentrated in warm grape-growing regions, such as the Riverina and the Hunter Valley. Such wines were characterized by generous fruit and oak flavors, moderate acidity, and relatively high alcohol levels. ${ }^{9}$ The general opinion is that although Australians continued to favor Australian chardonnay, they have moved toward more aromatic, crisp, and refreshing white wines in recent years, such as sauvignon blanc (and maybe semillon and pinot grigio), as consumer preferences for oak-driven rich chardonnay styles have declined. ${ }^{10-12}$ The industry responded in a timely manner, producing more chardonnay styles (so-called next-generation chardonnays) ${ }^{10}$ that were fresher and lower in alcohol ${ }^{13}$ and oak, but higher in fruit and acidity. However, there could still be a significant number of consumers who prefer traditional, old-fashioned, full-bodied chardonnay. The general view that consumers prefer lighter chardonnay wines produced in cool climates is not supported by increasing production of such wines, despite cooler-climate wines having a higher weighted average price.

As with many varietal wines, chardonnay falls into a number of categories (eg, basic, premium, iconic, etc) and within associated price points. This presents a problem when attempting to gain information about a specific category, since the information provided by most data-collection agencies refers to the combination of all categories, and thus can be misleading. For example, sales of ultrapremium and iconsector chardonnays have risen, while there are declining sales in the remaining price brackets. ${ }^{11,12}$ Detailed data on sales both in the domestic and export markets are lacking, partly due to the fact that large Australian retailers like Woolworths and Coles are reluctant to release sales information.

An additional problem chardonnay faces is that it has lost its social currency, as it is produced in a vast number of viticultural regions, leading to "unclear" styles and/or flavor profiles, whereas sauvignon blanc wines are more predictable. ${ }^{10}$ There is a view that consumers, especially in the UK, were simply tired of Australian chardonnay and moved to chardonnays from France (where it is also known as Chablis, white burgundy, blanc-de-blanc, Pouilly-Fuissé, etc),${ }^{14}$ Chile, South Africa, and other New World countries. ${ }^{11,12}$

It seems no single approach will ensure an increase in demand for chardonnay. To win back consumers and assure continuous success in both the domestic and export markets, the importance of region, clone selection, advances in viticultural management and winemaking, and appropriate marketing will all need to be considered in an integrated approach. The key, however, is to better understand the expectations of target consumers, since that will help identify desirable regional and clone characteristics and inform appropriate viticulture management/winemaking, as well as provide a marketing focus.

\section{Consumer attitudes and taste preference for chardonnay}

If the word "chardonnay" is entered into Google Scholar or Web of Knowledge, there will be around 26,000 hits. While there are a large number of articles about chardonnay, many only offer opinions. Where chardonnay has been used in research, insights into the wine itself are not provided. It is clear there is a need for an increase in reported empirical research on consumer behavior and sensory and perceptual factors related to chardonnay to inform decisions about chardonnay production and marketing. Consumer sensory research on other white varieties, eg, Hunter Valley semillon ${ }^{15,16}$ and New Zealand sauvignon blanc, ${ }^{17,18}$ has been reported, possibly more so than that on chardonnay.

\section{United States}

Yegge and Noble ${ }^{19}$ conducted a study in which ten inexpensive commercial California chardonnay wines, vintage 1997, were descriptively profiled by 14 trained judges and further rated by 126 novice and experienced chardonnay wine consumers for acceptance and purchase intent. "Acceptance" was based on sensory factors, such as aroma and flavor (using such descriptors as "oak", "butter", "citrus", "apple”, etc), while purchase intent was based on nonsensory wine attributes, such as price, growing region, label description, brand 
name, and label design. The largest variation in consumer flavor preference was observed between fruity and floral wines versus wines with low intensity of fruitiness but high in caramel, spice, and oak aromas. Acceptance was scored significantly higher than purchase intent, which suggested that purchase behavior depended on more than mere liking of a product. In addition, labels significantly influenced the attitude toward several of the wines, thereby demonstrating the importance of labeling. An Australian study by Bruwer et $\mathrm{al}^{20}$ confirmed that these choice cues were important in purchasing.

Martin et $\mathrm{al}^{21}$ and Martin and Durham ${ }^{22}$ studied the impact of three types of bottle closures - screw cap, synthetic, and natural cork - on consumer perceptions. Consumers were selected from Portland, Oregon from a pool of 2,000 subjects based on availability. They were interviewed through a screening questionnaire for age, sex, wine knowledge, and frequency of drinking 19 common beverages, such as fruit juice, dairy beverages, coffee, tea, and alcoholic beverages, including wine. The majority of the participants were aged between 24 and 55 years, with females slightly outnumbering males in all tests. Chardonnay from the vintage 2000 was bottled for 33 months before evaluation.

In the first experiment, "regular" wine consumers (ie, drank wine 2-3 times a month) could not detect differences between wine bottled with the three closure types when closure information was unknown, and were no more skilled in detecting a difference than "infrequent" wine consumers (ie, drank wine once a month or less). The researchers also concluded that liking, quality, purchase intent, and price expectation were rated in a significantly different way when consumers were informed about the closure type. At the time of these studies, knowledge about the type of closure strongly influenced liking, quality rating, and expected price, because wine was perceived to be of a lower quality when closed with synthetic cork and even more so when closed with a screw cap.

\section{Canada}

In other studies, Canadian chardonnay was analyzed for its sensory and compositional attributes by Cliff and Dever, ${ }^{23}$ later by Schlosser et al, ${ }^{24}$ and finally by Lesschaeve et al. ${ }^{7}$ In the first study, 16 chardonnay wines from 1993 and 25 chardonnay wines from 1988-1993 from British Columbia were profiled. Wine, wineries, and vintage differences were analyzed. The 161993 vintage wines were obtained from 12 wineries, and the 25 1988-1993 vintage wines were obtained from six of the 12 wineries. Wine styles were able to be discriminated, as some wineries produced fruity and floral wines, while others were more yellow, oaky, buttery, and astringent. Chemical analyses involved titratable acidity, $\mathrm{pH}$, absorbance, phenol, and alcohol content. Ten "experienced" judges evaluated the color, aroma and flavor of all wines. Correlates with the attributes fruit, sweetness, and perfume, as well as complex, yellow, oak, and alcohol, were found in the 1993 wines. Astringent and vegetal characteristics were found to be negatively correlated with fruit and sweetness, as were perceived acidity, complexity, yellow, and alcohol.

The older vintages were generally found to be more yellow and oaky with more diacetyl flavors, while the 1993 wines were fruitier. The differences were attributed to the influence of both aging and the cooler weather conditions. Chardonnay wines from Chablis, Mâconnais, and Napa Valley have also been associated with fruitiness, specifically ripe apple, melon, and pineapple characters. ${ }^{14}$ Among the disadvantages of the Cliff and Dever ${ }^{23}$ study were that several different vintages were investigated, leading to possible confounding effects. Further, bottle age was not taken into account, and the oldest wines were omitted from some of the analyses.

Schlosser et $\mathrm{al}^{24}$ analyzed 24 chardonnay wines from the Niagara Peninsula, one of the three distinct Ontario viticultural appellations, as well as chardonnays from California, Australia, and France for their chemical and sensory attributes. The general outcome of the study was that regional differences in topography, climate, and soil have limited impact on the distinctive sensory characteristics of chardonnay wines from the Niagara Peninsula. The findings were consistent with those of Noble and Ohkubo ${ }^{25}$ who found that chardonnay wines from California exhibited limited regional differentiation.

\section{Australia and New Zealand}

The Australian Wine Research Institute undertook a study in 2010 involving eight oaked and four unoaked commercial chardonnays in Australia, chosen for their chemical composition and sensory attributes. ${ }^{26}$ The selected wines were within the A\$8-\$20 price range and had less than $4 \mathrm{~g} / \mathrm{L}$ residual sugar. An expert panel separated the unwooded chardonnays widely across a three-dimensional principal componentanalysis map. In another experiment, 203 Sydney-based regular white wine drinkers evaluated 14 wines, including eight Riesling, two pinot gris, and four chardonnay (two oaked and two unwooded) for liking. ${ }^{26}$ Three consumer clusters with different preferences were identified.

Cluster 1 comprised $41 \%$ of the total sample tested, with people in that cluster preferring a chardonnay that exhibited 
high levels of oak flavor, hotness, butter, viscosity, fruit aftertaste, and yellow color. In contrast, cluster $3(36 \%)$ people preferred sweet wines with fruity aromas, such as citrus and pineapple, while cluster $2(22 \%)$ members liked mainly Riesling wines with strong citrus flavor and higher acidity. The two pinot gris wines were equally well liked by consumers, with a preference for bitter, cheesy, and astringent wines. The authors concluded that phenolics, even at low levels, have a negative influence on a considerable number of consumers, and that the consumer clusters identified in this study were reproducible and real. As such results suggest, opportunities exist for different market niches. Detailed data were not presented, information about sex, age, and other characteristics of the consumers who evaluated the wine was not reported, and data specific to chardonnay were limited.

In another study, King et $\mathrm{al}^{27}$ conducted a survey in which regular white wine consumers were segmented based on self-reported liking and knowledge of white wine styles. The study was based on the top white varieties sold in Australia, and represented a wide range of styles and flavors: chardonnay, Riesling, and sauvignon blanc from both Australia and New Zealand. A sample of 150 respondents, equally distributed between male and female consumers and age categories, were recruited from the Adelaide metropolitan district (South Australia). The participants were regular white wine purchasers $(\$ 10-\$ 20)$, had no tertiary wine education, and were not employed in the wine industry. It was found that the grape variety, region/country, brand name, and recommendation by friends were the major drivers for decision making, while technical comments on the back label, cork closure, and alcohol levels were the least important. The current study also investigated some of these choice factors in preference and wine buying. The major limitation of the King et $\mathrm{al}^{27}$ study was that price was not included as a purchase driver, even though it has been well established that it is one of the most important factors influencing purchase decisions. ${ }^{28,29}$

Bleibaum et $\mathrm{al}^{30}$ interviewed approximately 400 consumers from Australia and 300 from the US, primarily by means of an attitude and usage questionnaire. They concluded that closure type was an important purchase-intent driver, along with price, variety, and region. Participants preferred natural cork to synthetic cork, with screw caps having a negative impact on purchase intent, particularly for wines over AU\$15. For Australian consumers, price was of primary importance, followed by closure type, region, and variety. Unfortunately, no further information on this study was available, as it was conducted by the Tragon Consumer Marketing Group (http:// www.tragon.com). As is usual for work involving consumer attitudes, the fact that the study was conducted more than 7 years ago is now a limitation that needs to be taken into account. Attitude toward screw caps and subsequent perceptions of quality is one relationship that changes rapidly.

\section{Sociodemographics, consumption occasions, and choice cues}

Atkin et $\mathrm{al}^{31}$ suggested that a good starting point when evaluating how consumers make wine-buying decisions may be to look at differences by sex. Women tend to be superior in their sense of taste and smell, and they have a greater capacity to pick up subtleties in wine. ${ }^{31}$ It has been found that sex differences in wine consumption are likely to be associated more strongly with volume, and perhaps wine style and grape variety. ${ }^{20,32}$

Age-group issues are only one element that marketers should include in planning their marketing strategies. The belief is now widely held that for the world wine market to grow, more young drinkers must be introduced to wine during the critical years in their early to mid-20s, during which they form many consumption habits for life. ${ }^{33}$ Generally, consumers' wine consumption increases with age, peaking during the midlife stages before declining. ${ }^{29}$

Consumers rely both on extrinsic cues (price, brand name, packaging, store name, country of origin, color, etc) and intrinsic cues (taste, texture, aroma, etc) when assessing wine quality. It is also important to recognize that before sampling a wine, consumers must evaluate it primarily on the basis of their perception of the brand name. The wine-purchase decision is widely regarded as complicated ${ }^{34}$ and associated with a relatively high degree of perceived risk, ${ }^{29,35}$ which is in turn influenced by the consumption occasion for which the wine is bought. ${ }^{36,37}$

Different consumers display different product preferences for different wine-consumption occasions..$^{29,38,39}$ Bruwer et $\mathrm{al}^{29}$ identified six distinct wine-consumption occasions, namely gifting, normal at-home, celebration, cellaring wine to age, away from home when dining, and away from home with others. It was concluded that the decreasing order of importance in consumption occasions had an inverse relationship with the closeness of the relationship the wine consumers had with those with whom they may consume the wine they had purchased.

Clearly then, there is a dearth of information in the knowledge base about who the chardonnay consumer is, what their wine-consumption metrics are, the drivers of this consumption, and how their perceptions were formed and can be altered in future. Based on the indications previously 
discussed, and to give direction to our research, the following research questions were formulated:

- Who is the chardonnay drinker?

- What are the consumption metrics of the chardonnay drinker?

- What is the buying behavior of the chardonnay drinker like?

- What are the characteristics associated with chardonnay wine?

- What factors influence chardonnay consumption?

- What are the consumption occasions associated with chardonnay?

\section{Materials and methods}

A population sample was recruited in 2012 to be representative of Australian consumers. Participants were recruited through the market-research company Research Now, and were required to be at least 18 years of age and to consume wine at least once per fortnight. In order to achieve a balanced view of participants' perception of chardonnay, there was no requirement that participants consume chardonnay.

An invitation to complete the online questionnaire was sent to panelists matching the sampling criteria of the present study. Firstly, participants received an information statement outlining the nature of the questionnaire and what would be required of them, how the data collected would be utilized, that participant responses were anonymous, and that participation was voluntary. The information statement also contained the contact details of the principal investigator and appropriate ethics clearance, in the event that participants had any concerns or questions. Participants were required to read the information statement before accessing the questionnaire, and as such, informed consent was inferred by the participant having read the information statement and continuing on to complete the questionnaire. Participants then completed the five sections of the online questionnaire. The final sample size was 1,533 respondents. Data were analyzed using SPSS 21.0 software.

\section{Results and discussion Sociodemographic profile of the chardonnay consumer}

The demographic characteristics in Table 1 show that the sample was slightly weighted toward females (51\%), those mature in age, with $60 \%$ belonging to Generation $\mathrm{X}$ and the older-age generation (40-plus years old), the well educated (46\% had at least a 3-year university bachelor's degree), and with a high household income (\$87,142 per year).
Table I Sociodemographic characteristics of the chardonnay wine consumer

\begin{tabular}{|c|c|c|c|}
\hline Characteristic & $\begin{array}{l}\text { Males }(\%) \\
(n=752)\end{array}$ & $\begin{array}{l}\text { Females }(\%) \\
(n=78 I)\end{array}$ & $\begin{array}{l}\text { Overall }(\%) \\
(n=1,533)\end{array}$ \\
\hline Sex & 49.1 & 50.9 & 100.0 \\
\hline \multicolumn{4}{|l|}{ Age-group } \\
\hline 18-24 years & 9.2 & 10.4 & 9.8 \\
\hline $25-28$ years & 3.6 & 6.8 & 5.2 \\
\hline 29-34 years & 11.7 & 13.2 & 12.4 \\
\hline $35-39$ years & 12.2 & 12.4 & 12.3 \\
\hline 40-44 years & 7.4 & 7.6 & 7.5 \\
\hline $45-54$ years & 17.3 & 22.0 & 19.7 \\
\hline $55-64$ years & 16.1 & 14.3 & 15.2 \\
\hline $65+$ years & 22.5 & 13.3 & 17.9 \\
\hline Mean age (years) & 48.5 & 44.6 & 46.5 \\
\hline \multicolumn{4}{|l|}{ Education level } \\
\hline $\begin{array}{l}\text { No postsecondary } \\
\text { qualification }\end{array}$ & 52.3 & 55.1 & 53.8 \\
\hline $\begin{array}{l}\text { Undergraduate } \\
\text { postsecondary } \\
\text { qualification }\end{array}$ & 33.2 & 34.1 & 33.7 \\
\hline $\begin{array}{l}\text { Postgraduate } \\
\text { postsecondary } \\
\text { qualification }\end{array}$ & 14.5 & 10.8 & 12.5 \\
\hline \multicolumn{4}{|c|}{ Annual household income* level } \\
\hline$\leq \$ 30,000$ per year & 10.4 & 12.8 & 11.6 \\
\hline $\begin{array}{l}\$ 30,001-\$ 50,000 \\
\text { per year }\end{array}$ & 17.6 & 20.1 & 18.9 \\
\hline $\begin{array}{l}\$ 50,00 \mathrm{I}-\$ 75,000 \\
\text { per year }\end{array}$ & 19.7 & 17.9 & 18.8 \\
\hline $\begin{array}{l}\$ 75,00 \mathrm{I}-\$ 100,000 \\
\text { per year }\end{array}$ & 22.7 & 19.6 & 21.1 \\
\hline $\begin{array}{l}\$ 100,00 \mathrm{I}-\$ 200,000 \\
\text { per year }\end{array}$ & 25.9 & 25.5 & 25.7 \\
\hline$\$ 200,000$ plus per year & 3.7 & 4.1 & 3.9 \\
\hline $\begin{array}{l}\text { Annual household } \\
\text { income (mean) }\end{array}$ & $\$ 86,840$ & $\$ 87,424$ & $\$ 87,142$ \\
\hline $\begin{array}{l}\text { Number of persons } \\
\text { in household }\end{array}$ & Mean & Mean & Mean \\
\hline $\begin{array}{l}\text { Persons under } \\
18 \text { years old }\end{array}$ & 0.58 & 0.70 & 0.64 \\
\hline $\begin{array}{l}\text { Persons } 18 \text { years } \\
\text { and older }\end{array}$ & 2.22 & 2.21 & 2.22 \\
\hline $\begin{array}{l}\text { Total number of } \\
\text { persons in household }\end{array}$ & 2.80 & 2.91 & 2.86 \\
\hline $\begin{array}{l}\text { Persons } \geq 18 \text { years } \\
\text { old who drink wine }\end{array}$ & 1.95 & 1.91 & 1.93 \\
\hline
\end{tabular}

Note: *Income denoted in Australian dollars.

The Australian Bureau of Statistics ${ }^{40}$ determined that 23\% of the Australian population are tertiary educated, whilst the average income for a household is $\$ 58,748 .{ }^{40}$

It follows that the average person who consumed chardonnay tended to be well educated and generally more affluent than the average population, and thus was at a high socioeconomic level (Table 1). The results reflect a high level of income in the household to such an extent that about $63 \%$ 
earned more than the Australian national median household income. ${ }^{40}$ Given that the average size of the household was less than three persons (mean 2.86), which mostly included two adults and only one dependent child, it is clear that such a lifestyle product as wine was affordable at their discretion.

\section{Wine-consumption characteristics of the chardonnay consumer}

There is no universal standard for denoting wine-consumption frequency, and such a perspective on consumption is therefore very much country-specific. In most instances, the "at least once a week" consumer will be regarded as a regular wine drinker, which is the case in the UK, US, ${ }^{41,42}$ and Australia. ${ }^{20}$

Table 2 shows the consumption frequency of the chardonnay consumers. We note that $42 \%$ fit the once-a-week criterion, and were thus regular drinkers of chardonnay wine. Of the remainder, $35 \%$ drank chardonnay at least once a month, while $23 \%$ were clearly infrequent in their consumption of this varietal. It is also insightful that the average period that consumers had been drinking chardonnay was 16 years, thus denoting a considerable amount of experience.

Tables 3 and 4 provide insight into overall wine consumption and expenditure (Table 3 ), and by contrast chardonnay wine consumption and expenditure (Table 4). At the same time, the consumption differences (if any) between sexes and age-groups were also examined.

As far as total wine consumption is concerned, Table 3 shows that males consumed significantly more wine than females to the order of two bottles more per month $(P=0.000)$, and the households of the male respondents also spent significantly more on wine per month. Interestingly, females had a higher average spend per bottle purchased than males, which confirms a similar finding in the Australian market. ${ }^{29}$

The metrics of the respondents' consumption of the chardonnay varietal within their total wine consumption reveal some further insights. The first is that chardonnay consumption by sex proportion was split almost evenly, with females (51\%) holding

Table 2 Chardonnay-consumption frequency of the chardonnay wine consumers

\begin{tabular}{lll}
\hline Consumption frequency & $\%$ & Overall \% \\
\hline Daily & 2.3 & 2.3 \\
A few times a week & 20.0 & 22.3 \\
Once a week & 19.5 & 41.8 \\
Once a fortnight & 16.8 & 59.6 \\
Once a month & 18.4 & 78.0 \\
Less often than once a month & 23.0 & 100.0 \\
\hline
\end{tabular}

Note: Time period drinking chardonnay wine, 16.11 years.
Table 3 Monthly total wine consumption and expenditure by the wine consumers

\begin{tabular}{lllllll}
\hline $\begin{array}{l}\text { Consumption } \\
\text { factor (mean) }\end{array}$ & $\begin{array}{l}\text { Total } \\
(\mathbf{n}=1,533)\end{array}$ & $\begin{array}{l}\text { Males } \\
(\mathbf{n}=\mathbf{7 5 2})\end{array}$ & $\begin{array}{l}\text { Females } \\
(\mathbf{n}=\mathbf{7 8 I})\end{array}$ & $\boldsymbol{F}$ & df & $\boldsymbol{P}$ \\
\hline $\begin{array}{l}\text { Amount spent } \\
\text { per month }(\$)\end{array}$ & 104.27 & 115.27 & 93.70 & 19.139 & $\mathrm{I}$ & $0.000^{*}$ \\
$\begin{array}{l}\text { Consumption } \\
\text { per month } \\
\text { (bottles) }\end{array}$ & $6.6 \mathrm{I}$ & $7.6 \mathrm{I}$ & 5.64 & 52.810 & $\mathrm{I}$ & $0.000^{*}$ \\
$\begin{array}{l}\text { Average price } \\
\text { paid per }\end{array}$ & 15.78 & 15.15 & $16.6 \mathrm{I}$ & 0.392 & $\mathrm{I}$ & $0.53 \mathrm{I}$ \\
$\begin{array}{l}\text { bottle }(\$) \\
\text { Annual } \\
\text { household }\end{array}$ & 87,142 & 86,840 & 87,424 & 1.983 & $\mathrm{I}$ & 0.159 \\
income $(\$)$ & & & & & & \\
\hline
\end{tabular}

Notes: $* P<0.05$ (analysis of variance); grouping variables sex and chardonnay wine drinkers; monetary values expressed in Australian dollars.

only a slight ascendancy over males (49\%) (data not shown). Moreover, Table 4 shows that males drank significantly more chardonnay and spent significantly more money thereon than females $(P=0.000)$. This challenges the belief that chardonnay is a female drink, or at least confirms it no longer is.

The millennial age-group (18-39 years) has significantly higher income than Generation X and older people (40 years plus), and perhaps income is the explanatory variable for why millennials paid close to $\$ 17$ for a bottle of chardonnay, as opposed to the just over $\$ 13$ paid by older consumers. Older consumers, on the other hand, drank significantly more chardonnay, at 3.6 bottles, versus the 2.8 bottles of millennials $(P=0.000)$. The main chardonnay consumers are thus older males.

It was demonstrated earlier that although males drank significantly more chardonnay than females, their average spend per bottle did not vary much (Table 4). For the consumption occasions, in Table 5 we observe a pattern that the average amount spent per bottle by males and females differed significantly only for the normal at-home consumption occasion. Males spent more on wine to cellar for aging purposes, for normal consumption at home, celebration occasions, and away from home with others, while females spent more when the occasion was gift-giving, and away from home when dining. The scenario as far as age-groups are concerned is entirely different. Table 5 shows that younger millennial chardonnay consumers spent significantly more money on average per bottle than older consumers in the case of every consumption occasion.

\section{Purchasing from retail outlets and choice cues used by the chardonnay consumer}

Knowledge about where consumers source their wine is indicative of the outlet type that is convenient, where the wine 
Table 4 Monthly chardonnay-only wine consumption and expenditure by the wine consumers

\begin{tabular}{|c|c|c|c|c|c|c|}
\hline Consumption factor (mean) & $\begin{array}{l}\text { Total } \\
(n=I, 533)\end{array}$ & $\begin{array}{l}\text { Males } \\
(n=752)\end{array}$ & $\begin{array}{l}\text { Females } \\
(n=78 I)\end{array}$ & $\boldsymbol{F}$ & $d f$ & $P$ \\
\hline Amount spent per month (\$) & 47.98 & 53.94 & 42.25 & 17.089 & I & $0.000 *$ \\
\hline Consumption per month (bottles) & 3.30 & 3.74 & 2.89 & 16.696 & 1 & $0.000 *$ \\
\hline Average price paid per bottle $(\$)$ & 14.54 & 14.42 & 14.62 & 3.818 & $\mathrm{I}$ & 0.051 \\
\hline Annual household income (\$) & 87,142 & 86,840 & 87,424 & 0.054 & I & 0.816 \\
\hline Consumption factor (mean) & $\begin{array}{l}\text { Total } \\
(n=I, 533)\end{array}$ & $\begin{array}{l}<40 \text { Years } \\
(n=6 \mid 0)\end{array}$ & $\begin{array}{l}\geq 40 \text { Years } \\
(n=923)\end{array}$ & $\boldsymbol{F}$ & $d f$ & $P$ \\
\hline Amount spent per month $(\$)$ & 47.98 & 47.49 & 48.31 & 0.080 & I & 0.777 \\
\hline Consumption per month (bottles) & 3.30 & 2.80 & 3.64 & 15.619 & I & $0.000 *$ \\
\hline Average price paid per bottle $(\$)$ & 14.54 & 16.96 & 13.27 & 32.135 & 1 & $0.000 *$ \\
\hline Annual household income (\$) & 87,142 & 99,201 & 80,355 & 41.952 & I & $0.000 *$ \\
\hline
\end{tabular}

Notes: $* P<0.05$ (analysis of variance); grouping variables sex and age-group; monetary values expressed in Australian dollars.

is available, and of certain lifestyle habits, such as dining out, ${ }^{43}$ as shown in Table 6 .

As few differences have earlier been found between the sexes, we examined the differences between the age-groups. Table 6 indicates some clear pathways of shopping for chardonnay. In fact, the only outlet types for which a significant difference could not be found were specialty wine shops and bars/pubs in hotels. The pattern that emerged is that millennials bought significantly more often chardonnay wine from supermarkets/grocery stores, restaurants and winery tasting rooms, while the older age-groups bought chardonnay wine significantly more from large national liquor chains, directly online, and wine clubs/mail order.

It was outlined in the literature review that knowledge about the choice factors (cues) that influence people to buy chardonnay is essential to develop a better understanding of how they go about the decision-making process in a retail store. Participants were asked to respond to a series of wine-choice statements in relation to chardonnay (as shown in Figure 1) on a 7-point Likert scale (strongly disagree $=1$, indifferent $=4$, and strongly agree $=7$ ). As Figure 1 shows, price (mean 5.4, standard deviation [SD] 1.5), brand (mean 4.8 , SD 1.6), and region of origin (mean 4.65, SD 1.6) were considered to be the only agreeable choice factors.

Two-way analysis of variance (ANOVA) was used to assess significant mean differences based on age and sex for each of the aforementioned factors. In relation to sex main effects, females were more likely than males to consider brand $\left(F_{1,2012}=9.0, P=0.003\right.$, partial $\left.\eta^{2}=0.004\right)$ and price $\left(F_{1,2012}=9.6, P=0.002\right.$, partial $\left.\eta^{2}=0.01\right)$ to be important choice factors. An interaction effect was identified in which male participants aged 18-24 years were significantly more likely than males aged 55-64 years to consider health an important choice factor $\left(F_{5,972}=2.7, P=0.02, \eta^{2}=0.01\right)$. The factor "label" was characterized by younger participants being more likely to agree than older participants $\left(F_{5,2012}=4.1\right.$, $P=0.001$, partial $\eta^{2}=0.01$ ). Brand was considered significantly less important to participants aged $18-24$ years than

Table 5 Price paid per bottle for consumption occasion of chardonnay wine by consumers

\begin{tabular}{|c|c|c|c|c|c|}
\hline Consumption occasion & Overall & Males & Females & $\boldsymbol{F}$ & $P$, two-tailed \\
\hline Gift for someone & $\$ 20.15$ & $\$ 19.82$ & $\$ 20.42$ & 0.384 & 0.535 \\
\hline Cellaring (aging) it at home & $\$ 19.74$ & $\$ 20.48$ & $\$ 18.74$ & 10.002 & 0.317 \\
\hline Celebration occasion & $\$ 19.12$ & $\$ 19.52$ & $\$ 18.77$ & 0.672 & 0.412 \\
\hline Away from home when dining & $\$ 18.07$ & $\$ 17.97$ & $\$ 18.17$ & 0.084 & 0.772 \\
\hline Away from home with others & $\$ 15.88$ & $\$ 16.03$ & $\$ 15.76$ & 0.164 & 0.686 \\
\hline Normal at-home consumption & $\$ 14.28$ & $\$ 15.01$ & $\$ 13.53$ & 50.642 & $0.018 *$ \\
\hline Consumption occasion & Overall & $<\mathbf{4 0}$ Years & $\geq 40$ Years & $\boldsymbol{F}$ & $P$, two-tailed \\
\hline Gift for someone & $\$ 20.15$ & $\$ 22.51$ & $\$ 18.30$ & 19.203 & $0.000^{*}$ \\
\hline Cellaring (aging) it at home & $\$ 19.74$ & $\$ 23.03$ & $\$ 16.84$ & 13.319 & $0.000^{*}$ \\
\hline Celebration occasion & $\$ 19.12$ & $\$ 21.57$ & $\$ 17.14$ & 24.088 & $0.000 *$ \\
\hline Away from home when dining & $\$ 18.07$ & $\$ 19.84$ & $\$ 16.89$ & 17.129 & $0.000 *$ \\
\hline Away from home with others & $\$ 15.88$ & $\$ 17.63$ & $\$ 14.65$ & 20.784 & $0.000 *$ \\
\hline Normal at-home consumption & $\$ 14.28$ & $\$ 17.42$ & $\$ 12.31$ & 66.191 & $0.000 *$ \\
\hline
\end{tabular}

Notes: $* p<0.05$ (analysis of variance); grouping variables sex and age-group; monetary values expressed in Australian dollars. 
Table 6 Wine buying from retail outlet categories for chardonnay by age-group

\begin{tabular}{|c|c|c|c|c|c|}
\hline \multirow[t]{2}{*}{ Distribution-outlet category } & \multicolumn{3}{|c|}{ Wine volume \% purchases (mean) } & \multirow[t]{2}{*}{$\boldsymbol{F}$} & \multirow[t]{2}{*}{$P$} \\
\hline & $\begin{array}{l}\text { Overall \% } \\
(n=I, 533)\end{array}$ & $\begin{array}{l}<40 \text { Years \% } \\
(n=6 \mid 0)\end{array}$ & $\begin{array}{l}\geq 40 \text { Years } \% \\
(n=923)\end{array}$ & & \\
\hline $\begin{array}{l}\text { Large national liquor/specialty } \\
\text { wine stores }\end{array}$ & 50.1 & 46.4 & 52.4 & 10.128 & $0.001 *$ \\
\hline Supermarkets/grocery stores & 16.4 & 19.4 & 14.3 & |3.07| & $0.000 *$ \\
\hline $\begin{array}{l}\text { Independently owned specialty } \\
\text { wine shops }\end{array}$ & 11.0 & 10.7 & 11.3 & 0.246 & 0.620 \\
\hline Restaurants & 5.6 & 6.7 & 4.8 & 9.3983 & $0.002 *$ \\
\hline Winery tasting rooms & 5.2 & 6.7 & 4.3 & 11.846 & $0.001 *$ \\
\hline Internet direct online & 4.1 & 3.0 & 4.8 & 5.183 & $0.023 *$ \\
\hline Bars/pubs in hotels & 4.0 & 4.3 & 3.9 & 0.432 & 0.511 \\
\hline Wine clubs/mail order & 3.6 & 2.8 & 4.2 & 3.497 & $0.062 *$ \\
\hline Total & 100.0 & 100.0 & 100.0 & - & - \\
\hline Amount spent & $\$ 47.98$ & 47.49 & 48.31 & 0.080 & 0.777 \\
\hline
\end{tabular}

Note: $* P<0.05$ (analysis of variance).

to those aged 35-64 years, and participants aged $65+$ years considered it more important than those aged 18-44 years $\left(F_{5,2012}=5.6, P<0.001\right.$, partial $\left.\eta^{2}=0.01\right)$. Finally, participants aged 18-24 years were significantly less likely than all other age-groups to consider region in their choice of chardonnay $\left(F_{5,2012}=4.8, P<0.001\right.$, partial $\left.\eta^{2}=0.01\right)$.

In relation to age main effects, significant differences were identified for three choice factors (Figure 2). The factor "label" was characterized by younger participants being more likely to agree than older participants $\left(F_{5,2012}=4.1\right.$, $P=0.001$, partial $\eta^{2}=0.01$ ). Brand was considered significantly less important to participants aged 18-24 years than to those aged 35-64 years, and participants aged 65+ years considered it more important than those aged 18-44 years $\left(F_{5,2012}=5.6, P<0.001\right.$, partial $\left.\eta^{2}=0.01\right)$. Finally, participants aged 18-24 years were significantly less likely than all other age-groups to consider region in their choice of chardonnay $\left(\mathrm{F}_{5,2012}=4.8, P<0.001\right.$, partial $\left.\eta^{2}=0.01\right)$.

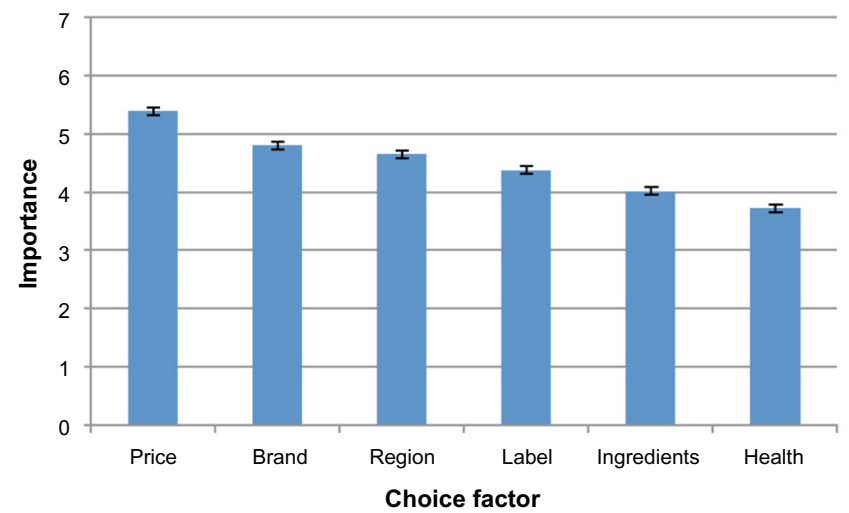

Figure I Choice-factor means for chardonnay in a retail store. Note: Importance scored on 7-point Likert scale.

\section{Characteristics associated with chardonnay's buying-influencing factors}

The final stage of the study focused on establishing the characteristics (sensory) that consumers associated with chardonnay, and the factors that influenced people to drink it. Table 7 shows the characteristics the consumers associated with chardonnay. These characteristics were derived from perusing the literature base, ${ }^{7,23,24}$ and hence consumers did not have the opportunity to provide their own descriptor(s).

Participants were asked to indicate which factors they believed to be characteristic of chardonnay on a 7-point Likert scale (strongly disagree $=1$, indifferent $=4$, and strongly agree $=7$ ). The scale returned a Cronbach $\alpha$-coefficient of 0.747 , which was above the minimum norm of 0.700 , and thus indicated an acceptable level of reliability. The results in Table 7 show that the participants believed chardonnay to be characterized by full flavor (mean 5.0, SD 1.2), lingering flavor (mean 4.8, SD 1.2), fruity flavors (mean 4.6, SD 1.4),

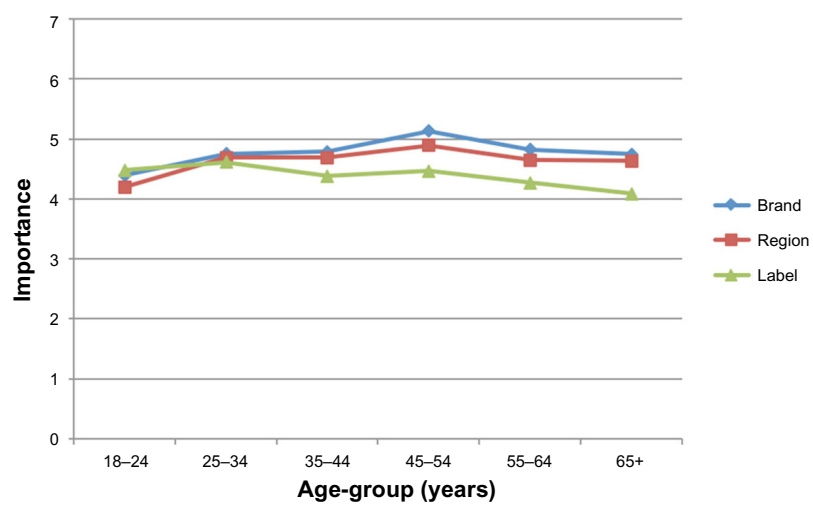

Figure 2 Age comparisons for choice factors. Note: Importance scored on 7-point Likert scale. 
Table 7 Characteristics associated with chardonnay by chardonnay-drinker age-groups

\begin{tabular}{|c|c|c|c|c|c|c|c|}
\hline Characteristics & Mean & SD & $\begin{array}{l}\text { SE of } \\
\text { mean }\end{array}$ & $d f$ & $\boldsymbol{F}$ & $P$ & $\eta^{2}$ \\
\hline ull flavor & 5.01 & 1.243 & 0.032 & 7 & 8.730 & $0.000 *$ & 0.039 \\
\hline ingeri & 4.83 & 1.208 & 0.031 & 7 & .832 & $0.56 I$ & 0.004 \\
\hline uity fla & 4.58 & 1.384 & 0.035 & 7 & 1.412 & 0.196 & 0.006 \\
\hline Yellow c & 4.46 & 1.437 & 0.037 & 7 & 12.163 & $0.000 *$ & 0.053 \\
\hline Drynes & 4.26 & 1.483 & 0.038 & 7 & 3.060 & 0.00 & 0.014 \\
\hline Oak & 4.23 & $1.54 \mid$ & 0.039 & 7 & 3.657 & $0.00 I^{*}$ & 0.017 \\
\hline harpness & 4.07 & 1.504 & 0.038 & 7 & 9.530 & $0.000 *$ & 0.042 \\
\hline Sweetness & 3.83 & 1.474 & 0.038 & 7 & 5.958 & $0.000 *$ & 0.027 \\
\hline $\begin{array}{l}\text { A heavy feeling } \\
\text { in the mouth }\end{array}$ & 3.46 & 1.575 & 0.040 & 7 & 16.963 & $0.000 *$ & 0.072 \\
\hline Bitterness & 3.06 & 1.536 & 0.039 & 7 & 28.186 & $0.000 *$ & 0.115 \\
\hline Vinegar flavor & 2.74 & 1.491 & 0.038 & 7 & 25.066 & $0.000 *$ & 0.103 \\
\hline
\end{tabular}

Note: $* P<0.05$ level (analysis of variance); grouping variable age-group (7-point Likert scale).

Abbreviations: SD, standard deviation; SE, standard error.

and yellow color (mean 4.5, SD 1.4). Participants disagreed with the notion of chardonnay being characterized by leaving a heavy feeling in the mouth (mean 3.5, SD 1.6), bitterness (mean 3.1, SD 1.5), or vinegar (mean 2.7, SD 1.5).

Two-way ANOVA was used to assess significant mean differences based on age and sex for each of the chardonnay characteristic factors. An interaction effect was identified for the characteristic of oak, in which females aged 25-54 years were more likely to consider chardonnay to be characterized by oak than females outside this age-group (Figure 3).

Finally, to assess the influencing factors leading to the participants' consumption of chardonnay, two-way ANOVA was used to assess significant mean differences based on age and sex for each of the factors shown in Table 8 .

In relation to age main effects, significant differences were identified for all the factors. The factors were characterized by polarization between the younger age-groups and the older

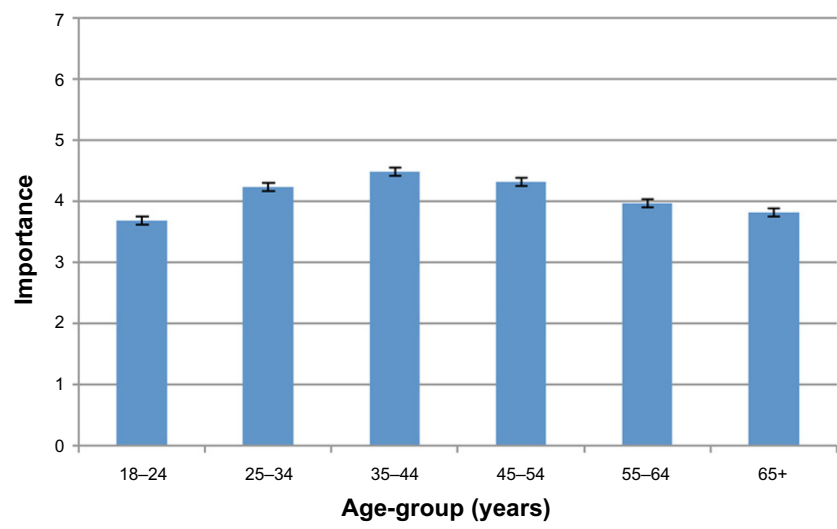

Figure 3 Oak as chardonnay characteristic based on age - female means. Note: Importance scored on 7-point Likert scale.
Table 8 Factors by which attitude toward chardonnay were influenced

\begin{tabular}{|c|c|c|c|c|c|c|c|}
\hline Factors & Mean & SD & $\begin{array}{l}\text { SE of } \\
\text { mean }\end{array}$ & $d f$ & $\boldsymbol{F}$ & $\boldsymbol{P}$ & $\eta^{2}$ \\
\hline $\begin{array}{l}\text { Personal } \\
\text { experience with } \\
\text { chardonnay }\end{array}$ & 5.05 & 1.566 & 0.040 & 7 & 5.412 & $0.000 *$ & 0.024 \\
\hline My friends & 3.68 & 1.709 & 0.044 & 7 & 8.504 & $0.000 *$ & 0.038 \\
\hline $\begin{array}{l}\text { Locations where } \\
\text { I purchase } \\
\text { chardonnay }\end{array}$ & 3.57 & 1.641 & 0.042 & 7 & 4.858 & $0.000 *$ & 0.022 \\
\hline $\begin{array}{l}\text { My spouse/ } \\
\text { significant other }\end{array}$ & 3.18 & 1.790 & 0.046 & 7 & 3.716 & $0.001 *$ & 0.017 \\
\hline Product advertising & 3.15 & 1.633 & 0.042 & 7 & 6.344 & $0.000 *$ & 0.028 \\
\hline Work colleagues & 3.09 & 1.652 & 0.042 & 7 & 8.914 & $0.000 *$ & 0.039 \\
\hline The media & 3.00 & 1.587 & 0.041 & 7 & 9.679 & $0.000 *$ & 0.043 \\
\hline Wine magazines & 3.00 & 1.659 & 0.042 & 7 & 19.713 & $0.000 *$ & 0.018 \\
\hline $\begin{array}{l}\text { My family } \\
\text { in general }\end{array}$ & 2.98 & 1.680 & 0.043 & 7 & 3.975 & $0.000^{*}$ & 0.080 \\
\hline My parents & 2.79 & 1.683 & 0.043 & 7 & 33.482 & $0.000^{*}$ & 0.133 \\
\hline $\begin{array}{l}\text { TV and film, } \\
\text { eg, Kath and Kim }\end{array}$ & 2.60 & 1.719 & 0.044 & 7 & $|8.84|$ & $0.000 *$ & 0.080 \\
\hline
\end{tabular}

Note: $* P<0.05$ (analysis of variance); grouping variables sex and age-group.

Abbreviations: SD, standard deviation; SE, standard error.

age-groups. In relation to sex main effects, males were more likely than females to consider their chardonnay attitudes to have been influenced by their spouse or significant other, the locations where they purchased chardonnay, and wine magazines. Conversely, females were more likely than males to consider their chardonnay attitudes to have been influenced by their own personal experience with wine.

In relation to sex main effects, males were more likely than females to consider their chardonnay attitudes to have been influenced by their spouse or significant other, the locations where they purchase chardonnay, and wine magazines. Conversely, females were more likely than males to consider their chardonnay attitudes to have been influenced by their own personal experience with wine. An interaction effect was identified for the factor concerned with the influence of work colleagues. Firstly, older male participants were less likely to consider their attitudes toward chardonnay to have been influenced by work colleagues than younger males. Secondly, female participants aged 25-34 years were more likely than female participants aged 55+ years to consider their attitudes to have been influenced by their work colleagues.

The findings elicited in this study are multifaceted, and contribute to a better understanding of the chardonnay drinker profile and its consumption metrics. As a baseline study, it lays a foundation upon which further investigations taking different angles can be based. 


\section{Conclusion}

An integrated approach is required to reverse the trend away from chardonnay and win back consumers in the domestic market. In addition to the influence of region, clone selection, and advances in viticultural management and winemaking, an understanding of consumer preferences and appropriate marketing are critical in order to meet the expectations of target groups. Wine tourism in the form of tasting room visits is an activity that would assist with educating consumers about chardonnay wine. ${ }^{44}$

The vast majority of participants liked and had a positive perception of chardonnay. Chardonnay was considered to be characterized by full, lingering, and fruity flavors, as well as yellow color. Males purchased and consumed larger quantities of chardonnay, although marginally more females consumed it.

The key, however, is to better understand the expectations of target consumers, since that will help identify desirable regional and clone characteristics and inform appropriate viticulture management/winemaking, as well as provide a marketing focus.

\section{Acknowledgment}

The authors thank the Australian Grape and Wine Authority (formerly Grape and Wine Research and Development Corporation) for financial support of this research.

\section{Disclosure}

The authors report no conflicts of interest in this work.

\section{References}

1. Scott J. The future of Australia's wine industry: challenges and change. Aust N Z Wine Ind J. 2010;25(1):38-40.

2. Rowley M. The nation's vineyard - 40 years of evolution. Wine Vitic J. 2012;27(1):74-75.

3. Wall PJ. Who wants new clones of grapevines in Australia? In: Aspects of Grapevine Improvement in Australia: Proceedings of a Seminar Organised by the Australian Society of Viticulture and Oenology, Canberra, Australian Capital Territory. Adelaide: Australian Society of Viticulture and Oenology; 1986.

4. Winemakers' Federation of Australia. Vintage Report. Adelaide: Winemakers' Federation of Australia; 2013.

5. Australian Bureau of Statistics. Vineyard Estimates, Australia, 2011-12. Canberra: Australian Bureau of Statistics; 2013.

6. Winemakers' Federation of Australia. Wine Sales in Australia - Quarterly Report. Adelaide: Winemakers' Federation of Australia; 2014.

7. Lesschaeve I, Bowen A, Bruwer J. Determining the impact of consumer characteristics to project sensory preferences in commercial white wines. Am J Enol Vitic. 2012;63(4):487-493.

8. MacDonald JB, Saliba AJ, Bruwer J. Wine choice and drivers of consumption explored in relation to generational cohorts and methodology. J Retailing Consum Serv. 2013;20(3):349-357.

9. Paterson T. Australian chardonnay: past, present and future. JWine Res. 2004;15(2):135-169.
10. Curtin BD, Bellon JR, Bartowsky EJ, et al. Harnessing AWRI's yeast and bacterial research to shape 'next-gen' chardonnay part 1: 'Wild' and 'non-conventional' yeast. Wine Vitic J. 2011;26(1):15-20.

11. Keys T. Chardonnay part 1: The numbers game. Aust $N Z$ Wine Ind J. 2010;25(5):48-54.

12. Keys T. Chardonnay part 2: The story continues. Wine Vitic J. 2011; 26(1):70-74.

13. Bruwer J, Jiranek V, Halstead L, Saliba AJ. Lower alcohol wines in the UK market: Some baseline consumer behaviour metrics. Br Food $J$. 2014;116(7):1143-1161.

14. Robinson J. Vines, Grapes and Wines. New York: Alfred A Knopf; 1986.

15. Blackman J, Saliba A. Sensory characterization of Hunter Valley semillon using descriptive analysis. Flavour Fragr J. 2009;24(5):238-244.

16. Blackman J, Saliba AJ, Schmidtke L. Sweetness acceptance of novices, experienced consumers and winemakers in Hunter Valley semillon wines. Food Qual Prefer. 2010;21(7):679-683.

17. Francis LI, Sefton MA, Williams PJ. Sensory descriptive analysis of the aroma of hydrolysed precursor fractions from semillon, chardonnay and sauvignon blanc grape juices. J Sci Food Agric. 1992;59(4): 511-520.

18. Parr WV, Green JA, White KG, Sherlock RR. The distinctive flavour of New Zealand sauvignon blanc: sensory characterisation by wine professionals. Food Qual Prefer. 2007;18(6):849-861.

19. Yegge JM, Noble AC. The identification of sensory and non-sensory attributes of California chardonnay wines that influence acceptance and purchase intent for different segments of consumers. Proceedings of the ASEV 50th Anniversary Meeting, Seattle, Washington. Am J Enol Vitic. 2000;51:28-31.

20. Bruwer J, Saliba AJ, Miller B. Consumer behaviour and sensory preference differences: Implications for wine product marketing. J Consum Mark. 2011;28(1):5-18.

21. Martin AB, Jorgensen EM, Kennedy JA, Ferrier J. Effects of bottle closure type on consumer perceptions of wine quality. Am J Enol Vitic. 2007;58(2):182-191.

22. Martin AB, Durham CA. Effects of wine bottle closure type on consumer purchase intent and price expectation. Am J Enol Vitic. 2007;58(2): 192-201.

23. Cliff MA, Dever MC. Sensory and compositional profiles of British Columbia chardonnay and pinot noir wines. Food Res Int. 1996;29(3): 317-323.

24. Schlosser J, Reynolds AG, King M, Cliff M. Canadian terroir: sensory characterization of chardonnay in the Niagara Peninsula. Food Res Int. 2005;38(1):11-18.

25. Noble, AC, Ohkubo T. Evaluation of flavor of California chardonnay wines. Poster presented at: First International Symposium - Le Sostanze Aromatiche dell'Uva e del Vino; July 25-27, 1989; San Michele all'Adige, Italy.

26. Francis LI, Osidacz P, Bramley B, et al. Linking wine flavour components, sensory properties and consumer quality perceptions. Aust Wine Ind J. 2010;25(5):18-23.

27. King ES, Johnson TE, Bastian SE, Osidacz P, Francis LI. Consumer liking of white wines: segmentation using self-reported wine liking and wine knowledge. Int J Wine Bus Res. 2012;24(1):33-46.

28. Mueller S, Lockshin L, Saltman Y, Blanford J. Message on a bottle: the relative influence of wine back label information on wine choice. Food Qual Prefer. 2010;21(1):22-32.

29. Bruwer J, Fong M, Saliba AJ. Perceived risk, risk-reduction strategies (RRS) and consumption occasions: roles in the wine consumer's purchase decision. Asia Pa J Mark Logist. 2013;25(3):369-390.

30. Bleibaum RN, Lattey KA, Francis IL. Conjoint research for consumer perception of wine closure options and their impact on purchase interest in the United States and Australia. Poster presented at: Sixth Pangborn Sensory Science Symposium; August 7-11, 2005; Harrogate, UK.

31. Atkin T, Nowak L, Garcia R. Women wine consumers: Information search and retailing implications. Int J Wine Bus Res. 2007;19(4): $327-339$. 
32. Bruwer J, Lesschaeve I, Campbell BL. Consumption dynamics and demographics of Canadian wine consumers: retailing insights from the tasting room channel. J Retailing Consum Serv. 2012;19(1): 45-58.

33. Bruwer J. Marketing wine to generation-X consumers through the winery cellar door. Aust N Z Grapegrow Winemak. 2012;(467): 67-70.

34. Lockshin L, Jarvis W, d'Hauteville F, Perrouty JP. Using simulations from discrete choice experiments to measure consumer sensitivity to brand, region, price, and awards in wine choice. Food Qual Prefer. 2006;17(3):166-178.

35. Lacey S, Bruwer J, Li E. The role of perceived risk in wine purchase decisions in restaurants. Int J Wine Bus Res. 2009;21(2):99-117.

36. Aqueveque C. Extrinsic cues and perceived risk: the influence of consumption situation. J Consum Mark. 2006;23(5):237-247.

37. Bruwer J, Burrows N, Chaumont S, Li E, Saliba AJ. Consumer involvement and associated behaviour in the UK high-end retail offtrade wine market. Int Rev Retail Distrib Consum Res. 2014;24(2): $145-165$.
38. Hirche M, Bruwer J. Buying a product for an anticipated consumption situation: observation of high and low involved wine buyers in a retail store. Int J Wine Bus Res. 2014;26(4):295-318.

39. Crump AM, Johnson TE, Bastian SE, Bruwer J, Wilkinson KL. Consumers' knowledge of and attitudes towards the role of oak in winemaking. Int J Wine Res. 2014;6:21-30.

40. Australian Bureau of Statistics. Household Income and Income Distribution, Australia. Canberra: Australian Bureau of Statistics; 2013.

41. Wine Intelligence. UK Wine Market Landscape Report. London: Wine Intelligence; 2010.

42. Wine Market Council. Wine Market Council's 2011 Consumer Tracking Study. St Helena (CA): Wine Market Council; 2011.

43. Reid M, Li E, Bruwer J, Grunert K. Food-related lifestyles in a crosscultural context: comparing Australia with Singapore, Britain, France and Denmark. J Food Prod Mark. 2001;7(4):57-75.

44. Alant K, Bruwer J. Winery visitation sets: intra-regional spatial movement of wine tourists in branded wine regions. Int J Wine Bus Res. 2010;22(2):191-210.
International Journal of Wine Research

\section{Publish your work in this journal}

The International Journal of Wine Research is an international, peer-reviewed open-access, online journal focusing on all scientific aspects of wine, including: vine growing; wine elaboration; human interaction with wine; and health aspects of wine. The journal provides an open access platform for the reporting

\section{Dovepress}

of evidence based studies on these topics. The manuscript management system is completely online and includes a very quick and fair peer-review system, which is all easy to use. Visit http://www.dovepress.com/testimonials.php to read real quotes from some of our published authors.

Submit your manuscript here: http://www.dovepress.com/international-journal-of-wine-research-journalisease-journal 